\title{
ANALISIS NERACA AIR \\ DAERAH ALIRAN SUNGAI (DAS) WAY SUKADANA \\ KABUPATEN LAMPUNG TIMUR \\ LAMPUNG
}

\author{
(Maton Tyasmadi ${ }^{1)}$ Aprizal, S.T., M.T. ${ }^{2)}$ \\ ${ }^{1)}$ Staf Teknik O\&P Sumber Daya Air II, Satker O\&P SDA BBWS Mesuji Sekampung \\ ${ }^{2)}$ Staf Pengajar Departemen Teknik Sipil, Fakultas Teknik Universitas Bandar Lampung
}

\begin{abstract}
ABSTRAK
Daerah Aliran Sungai (DAS) Way Sukadana adalah bagian dari Daerah Aliran Sungai (DAS) Way Sekampung yang secara administratif terlctak di kabupaten Lampung Timur. Penulisan ini menganalisis keseimbangan antara kebutuhan dan ketersediaan air di DAS Way Sukadana.Dalam penelitian ini kebutuhan air yang dianalisis adalah kebutuhan air penduduk, kebutuhan air ternak, kebutuhan air irigasi dan kebutuhan air industri. Kebutuhan air akan dibandingkan dengan ketersediaan air di DAS Way Sukadana, Analisis debit ketersediaan air menggunakan metode NRECA. Metode NRECA adalah suatu metode simulasi hujan debit yang diperkenalkan oleh Norman H. Crauford pada tahun 1985. Model NRECA merupakan model konsepsi yang bersifat deterministik. Model konsepsi adalah model dengan basis teori, sedang sifat deterministik adalah penggunaan persamaan dan rumus semi empiris untuk menginterpretasikan fenomena proses fisiknya (Trisnoadhy, 2011). Hasil dari analisis didapatkan bahwa Daerah Aliran Sungai (DAS) Way Sukadana berada pada level surplus dan memiliki debit andalan rata-rata sebesar 228,22 $\mathrm{m}^{3} /$ detik. Debit andalan tersebut sangat mampu untuk memenuhi kebutuhan air irigasi sebesar $42,34 \mathrm{~m}^{3} /$ detik pada tahun 2019 dan sampai dengan 10 (sepuluh) tahun mendatang sebesar 44,04 $\mathrm{m}^{3} /$ detik pada tahun 2029 Daerah Aliran Sungai (DAS) Way Sukadana masih berada pada level surplus.
\end{abstract}

Kata kunci : DAS Way Sukadana, Neraca Air, Debit Andalah, Kebutuhan Air.

\section{PENDAHULUAN}

\section{Latar Belakang}

Sungai Way Sukadana adalah salah satu sungai di Kabupaten Lampung Timur yang rawan terhadap banjir. Sungai Way Sukadana merupakan bagian dari DAS Way Sekampung yang berada pada wilayah administratif Kabupaten Lampung Timur. Wilayah administrasi Kecamatan Sukadana terdiri dari 20 desa, Kecamatan Way Bungur sebanyak 20 desa, Kecamatan Purbolinggo sebanyak 12 desa dan Kecamatan Bumi Agung sebanyak 7 desa. Berdasarkan hasil inventarisasi dengan cara penelusuran Sungai Way Sukadana, diketahui panjang Sungai Way Sukadana sepanjang $23.8 \mathrm{Km}$ yang bermuara di Sungai Way Pegadungan.

Daerah aliran sungai Way Sukadana merupakan DAS yang sangat penting dalam mendukung berbagai fungsi sosial dan ekonomi masyarakat di sepanjang daerah pengaliran sungainya tersebut. Sebagai bagian dari Kawasan Lampung Timur yang dari tahun ke tahun mengalami perkembangan dan cenderung tidak terkendali, maka fungsi utama daerah aliran sungai Way Sukadana sebagai kawasan resapan air semakin berkurang. Hal ini disebabkan karena berubahnya fungsi kawasan tersebut sebagai daerah resapan air menjadi lahan pertanian, sementara kawasan pertanian berubah pula fungsinya (terkonversi) menjadi areal 
pemukiman. Perubahan fungsi tersebut terjadi karena semakin tingginya tuntutan

\section{Rumusan Masalah}

Berdasarkan uraian latar belakang di atas ada beberapa rumusan masalah yaitu :

1.Bagaimana menghitung debit andalan

$\left(\mathrm{Q}_{80}\right)$ ?

2.Bagaimana menghitung ketersediaan air menggunakan metode NRECA ?

\section{Batasan Masalah}

Dalam penulisan ini masalah dan pembahasannya terbatas pada :

1. Daerah penelitian adalah di Daerah Aliran Sungai Way Sukadana 2. pemukiman sekitar dan juga lahan lahan pertanian warga sekitar Daerah Aliran Sungai Way Sukadana.

2. Pokok pembahasan adalah membandingkan apakah kebutuhan dan ketersediaan air (neraca air) yang nantinya akan di dapatkan hasil apakah tercukupi atau tidak.

\section{Maksud dan Tujuan Penelitian \\ Maksud Penelitian}

1. Menghitung kebutuhan air domestik, kebutuhan air industri, kebutuhan air irigasi, dan kebutuhan air ternak di Daerah Aliran Sungai (DAS) Way Sukadana.

2. Menghitung ketersediaan air di Daerah Aliran Sungai (DAS) Way Sukadana.

3. Memproyeksikan kecukupan kebutuhan air apakah ketersediaan air di Daerah Aliran Sungai (DAS) Way Sukadana mencukupi atau tidak (neraca air).

\section{Tujuan Penelitian}

1. Mengetahui beşar kebutuhan air penduduk, ternak, irigasi dan industri di daerah alira11 sungai (DAS) Way Sukadana.

2. Mengetahui potensi ketersediaan air di daerah aliran sungai (DAS) Way Sukadana

3. Mengetahui keseimbangan antara kebutuhan dan ketersediaan air pada penyediaan

lahan

daerah aliran sungai (DAS) Way Sukadana.

\section{mManfaat Penelitian}

Mmanfaat penelitian ini adalah :

. Memberi masukan atau tambahan informasi terhadap pihak terkait dalam hal ini teknik management lingkungan hidup terhadap ketersediaan air di Daerah Aliran Sungai Way Sukadana khusunya.

Mengetahui kebutuhan air dan ketersediaan air yang berada di Daerah Aliran Sungai Way Sukadana sehingga didapatkan solusi untuk penanganannya.

\section{Tinjauan Pustaka}

Dalam kehidupan manusia air merupakan sumber daya alam yang sangat dibutuhkan, dan dalam sistem tata lingkungan, air adalah unsur lingkungan.

Kebutuhan manusia akan kebutuhan air selalu meningkat dari waktu ke waktu, bukan saja karena meningkatnya jumlah manusia yang memerlukan air tersebut, melainkan juga karena meningkatnya intensitas dan ragam dari kebutuhan akan air, (Silalahi.M.D., 2002).

Ketersediaan air yang sulit diatur dan diprediksi dengan akurat dikarenakan oleh ketersediaan air mengandung unsur variabilitas ruang (spatial variability) dan variabilitas waktu (temporal variability) yang sangat tinggi. Konsep siklus hidrologi adalah bahwa jumlah air di suatu luasan tertentu di hamparan bumi dipengaruhi oleh masukan (input) dan keluaran (output) yang terjadi. Kebutuhan air di kehidupan kita sangat luas dan selalu diinginkan dalam jumlah yang cukup pada saat yang tepat. Oleh karena itu, analisis kuantitatif dan kualitatif harus dilakukan secermat mungkin agar dapat dihasilkan informasi yang akurat untuk perencanaan dan 
pengelolaan sumberdaya air.Kebutuhan akan air dikategorikan dalam kebutuhan kebutuhan air yang digunakan untuk keperluan rumah tangga yaitu untuk keperluan minum, masak, mandi, mencuci pakaian serta keperluan lainnya,

\section{METODE PENELITIAN}

Metode yang digunakan pada penelitian ini adalah metode servey dengan tahapan persiapan data, pengumpulan data dan analisis data. Lokasi penelitian terletak

\section{Pengumpulan Data}

Data yang digunakan dalam penelitian ini berupa data sekunder dari berbagai sumber. Data sekunder yang diperlukan antara Iain:

1. DAS Way Sukadana

2. Data kependudukan

3. Data peternakan

4. Data industri

5. Data penggunaan Iahan irigasi yang ada disekitar DAS Way Sukadana

6. Data hujan dan klimatologi

7. Peta Tofografi dan peta penggunaan Iahan DAS Way Sukadana

Metode yang digunakan pada penelitian ini adalah metode survey dengan tahapan persiapan data, pengumpulan data dan analisis data.

\section{Tahap Persiapan}

Tahap persiapan yang dimaksud adalah untuk mempermudah jalannya suatu penelitian, seperti studi pustaka yang dimaksudkan untuk mendapatkan arah dan wawasan sehingga mempermudah dalam pengumpulan data, analisis maupun dalam penyusunan hasil penelitian. air domestik dan non domestik. Kebutuhan air domestik adalah sedangkan kebutuhan air non domestik digunakan untuk kantor, tempat ibadah, niaga dan lain-lain.

\section{Lokasi Penelitian}

di Sungai Way Sukadana. DAS Way Sukadana masuk kedalam DAS Way Sekampung dengan luas DAS Sungai Way Sukadana seluas 23,8 km2.

Pengumpulan Data

Data sekunder yang digunakan dalam penelitian ini diperoleh langsung dari catatan-catatan yang sudah ada dan diperoleh dari instansi-instansi terkait:

\section{a. Data Hidrologi}

Data ini menyangkut data hujan pada daerah yang mempengaruhi dalam perencanaan. Untuk mengetahui data curah hujan diambildaripengamatan curah hujan di stasiun pengamatan, data hidrologi digunakan untuk menghitung besar debit andalan.

\section{b. Data Klimatologi}

Data Klimatologi diperlukan untuk mengetahui kondisi klimatologi dari daerah tersebut sehingga dapat dihitung kebutuhan air yang diperlukan.Data klimatologi terdiri dari:

Temperatur bulanan rata-rata $\left(\mathrm{C}^{0}\right)$

- Kecepatan angin rata-rata $(\mathrm{m} / \mathrm{dt})$

- Kelembaban udara relatifrata-rata $(\%)$

- Lamanya penyinaran matahari rata- rata $(\%)$

c. Data BPS (Ditjen Cipta Karya)

Digunakan untuk menghitung kebutuhan air penduduk. 
d. Data rencana dan realisasi tanam (FAO)

Digunakan untuk menganalisis kebutuhan air untuk irigasi.

e. Data KP/PT Industri (Kementrian PU)

Digunakan untuk menganalisis kebutuhan air untuk industri.

f. Data Peternakan (Ditjen Cipta Karya)

Digunakan untuk menganalisis jumlah kebutuhan air untuk peternakan.

\section{Analisis Data}

Analisis Debit Andalan (Ketersediaan

Air)

Data hidrologi dan data tofografi yang telah diperoleh selanjutnya dianalisis untuk mencari debit andalan (ketersediaan air yang ada). Debit andalan adalah debit sungai dapat diandalkan untuk memenuhi kebutuhan air di daerah layanannya. Metode yang dipakai dalam menghitung ketersediaan air adalah metode NRECA. Metode ini menstimulasikan kesetimbangan air bulanan pada suatu daerah tangkapan yang ditujukan untuk menghitung total run off dari nilai curah hujan bulanan, evaporasi, kelembaban tanah, dan ketersediaan air tanah. Langkah-langkah dalam analisis debit andalah yang diperlukan untuk model NRECA ini adalah hujan bulanan, evapotranspirasi, temperatur rata-rata bulanan, sinar matahari, kelembaban relatif, kecepatan angin, kondisi awal kadar kelembaban tanah, tampungan awal air tanah, indeks soil moisture storage capacity pada daerah tangkapan, presentase run offyang mengalir pada jalur surfsurface dan persentase air yang masuk menjadi aliran air tanah.

Analisis kebutuhan air total

Dari kebutuhan air rumah tangga, kebuthan air irigasi, kebutuhan air industri, dan kebutuhan air peternakan (domestik dan non-domestik) yang telah diperoleh selanjutnya dianalisis untuk mencari kebutuhan air baku yang dibutuhkan.

Analisis Neraca Air (Water Balance)

Melakukan analisa neraca air (water balance) pada masing-masing daerah layanan dari ketersediaan dan kebutuhan air hasil perhitungan langkah sebelumnya.

Analisis Kondisi DAS Way Sukadana Berdasarkan analisis neraca air sebelumnya didapatkan kondisi daerah DAS Way Sukadana yang mengalami defisit dan surplus untuk kondisi saat ini. 
Bagan Alir Penelitian

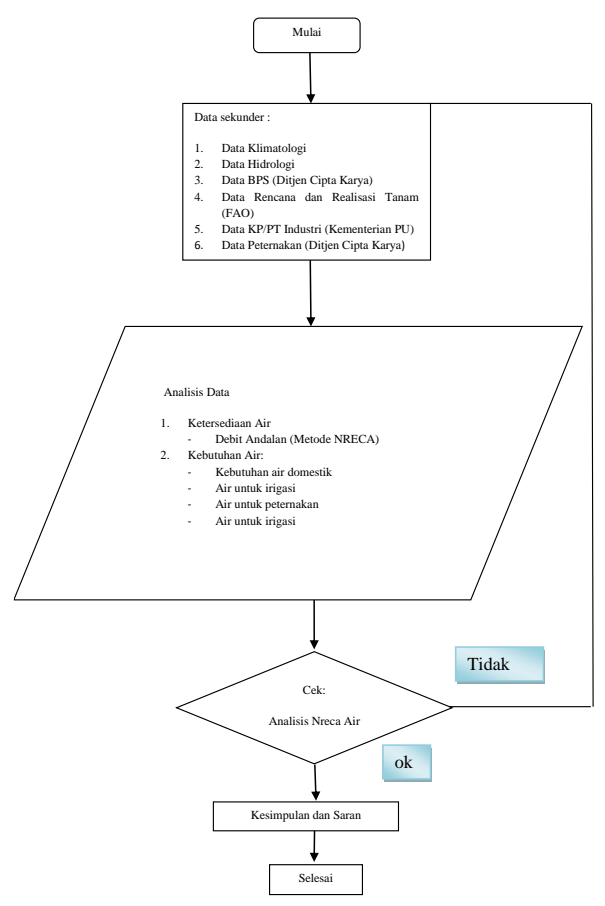

Bagan Alir Penelitian

\section{HASIL DAN PEMBAHASAN}

4.1 Data

Dalam penelitian ini, hasil dan pembahasan menggunakan data curah hujan juga data kependudukan. Data curah hujan yang dipakai adalah data curah hujan selama 10 tahun terakhir yaitu tahun 20102019. Data curah hujan diperoleh dari Balai Besar Wilayah Sungai Mesuji Sekampung (BBWSMS). Sedangkan data kependudukan di peroleh dari Badan Pusat Statistik. Pada penelitian ini diperlukan data jumlah penduduk, ternak, irigasi dan juga industri di 4 (empat) kecamatan yang berada di kabupaten Lampung Timur. Jumlah penduduk pada tahun 2019 disajikan pada tabel Jumlah kependudukan yang diperoleh dari Badan Pusat Statistik pada tahun 2019.
Tabel 4.1 Jumlah Penduduk Di Kabupaten Lampung Timur

\begin{tabular}{|c|c|c|c|}
\hline$\$ 0$ & Nama IID & Luas $\left(\left\{\mathbf{m}^{2} \mathbf{l}\right)\right.$ & Jumlah Penduduk (Jira) \\
\hline 1 & Sukadana & 754,77 & 70.306 \\
\hline 2 & Way Bungur & $5 j$ & 24.603 \\
\hline 3 & Pubolingego & 61,58 & 84.350 \\
\hline 4 & Bumi Agung & 101,39 & 35.030 \\
\hline \multicolumn{2}{|c|}{ DAS NTar Sukadama } & 992,74 & 214.289 \\
\hline
\end{tabular}

Sumber: Badan Pusat Statistik (BPS)

Provinsi Lampung, 2019 
Tabel 4.2 Tabel Thieseen Daerah Aliran Sungai Way Sukadana

\begin{tabular}{|c|c|c|c|c|}
\hline No & Sub DAS & Thiesen & Luas & $\%$ \\
\hline 1 & Purbolinggo & $\mathrm{PH} 111$ & 52,13 & 14,25 \\
\hline 2 & Sukaraja Tiga & R 142T & 20,61 & 5,63 \\
\hline 3 & Sekampung & $\mathrm{PH} 183$ & 42,81 & 11,70 \\
\hline 4 & LebakBumi & R 126 & 144,13 & 39,39 \\
\hline 5 & Nuban & $\mathrm{PH} 185$ & 0,09 & 0,02 \\
\hline 6 & Raman Utara & $\mathrm{PH} 186$ & 1,58 & 0,43 \\
\hline 7 & Way Bungkuk & $\mathrm{PH} 112$ & 84,52 & 23,10 \\
\hline 8 & Bendung Garongan & $\mathrm{PH} 110$ & 20,04 & 5,48 \\
\hline \multicolumn{3}{|c|}{ Luas Total } & 365,91 & 100 \\
\hline
\end{tabular}

Sumber: Balai Besar Wilayah Sungai Mesuji Sekampung (BBWSMS), 2019

- Luas DAS Way Sukadana : 365,91 km²

- Luas Poligon Thieseen stasiun hujan Purbolinggo : 52,13 $\mathrm{km}^{2}$

- Luas Poligon Thieseen stasiun hujan sukaraja tiga $: 20,61 \mathrm{~km}^{2}$

- Luas Polígon Thieseen stasiun hujan Sekampung : $42,81 \mathrm{~km}^{2}$

- Luas Poligon Thieseen stasiun hujan Lebak Bumi : 144,13 km²

- Luas Poligon Thieseen stasiun hujan Nuban : $0,09 \mathrm{~km}^{2}$

- Luas Poligon Thieseen stasiun hujan Raman Utara $\quad: \quad 1,58$ $\mathrm{km}^{2}$

- Luas Poligon Thieseen stasiun hujan Way Bungkok : 84,52 $\mathrm{km}^{2}$

- Luas Poligon Thieseen stasiun hujan Bendung Garongan : 20,04 $\mathrm{km}^{2}$

- Koef Thieseen Purbolinggo $: \frac{14,25}{100}=0,1425$

- Koef Thieseen Sukaraja Tiga $: \frac{5,63}{100}=0,0563$

- Koef Thieseen Sekampung $: \frac{11,70}{100}=0,1170$

- Koef Thieseen Lebak Bumi $: \frac{39,39}{100}=0,3939$

- Koef Thieseen Nuban $: \frac{0,02}{100}=0,0002$

- Koef Thieseen Raman Utara $: \frac{0,43}{100}=0,0043$

- Koef Thieseen Way Bungkuk $: \frac{23,10}{100}=0,2310$

- Koef Thieseen Bendung Garongan : $\frac{23,10}{100}=0,0548$

Contoh perhitungan hujan daerah harian maksimum tahun 2010 adalah :

- Hujan wilayah (P. Wilayah) tahun $2010=(102 \times 0,1425)+$ $(43 \times 0,0563)+$ $(97,5 \times 0,117)+(110,5$ $\mathrm{x} 0,3939)+(110,5 \times 0,0002)$ $+(175,5 \times 0,0043)+(116 \times 0,231)$ $+(142 \times 0,0548)=107,2 \mathrm{~mm}$ 
Setelah didapat nilai hujan wilayah bulanan per-dua minggu pada tahun 2010-2019, selanjutnya akan didapat nilai rerata hujan dengan merataratakan hujan wilayah bulanan dari tahun 2010-2019 per-dua minggunya. Untuk menghitung ketersediaan air diperlukan data P80 yang didapat dari perhitungan hujan wilayah bulanan pada tabel 4.3

Tabel hasil perhitungan hujan wilayah bulanan per-dua minggu daerah aliran sungai (DAS) Way Sukadana dapat dilihat pada Tabel 4.3 dibawah.

\section{Simulasi Hujan-Debit Dengan Metode NRECA}

Perhitungan ketersediaan air dilakukan untuk mengetahui jumlah air yang tersedia dari sumber air utama untuk memenuhi kebutuhan air yang ada. Metode yang dapat digunakan untuk menghitung
Tabel 4.3Tabel Hujan Wilayah Daerah Aliran Sungai Way Sukadana

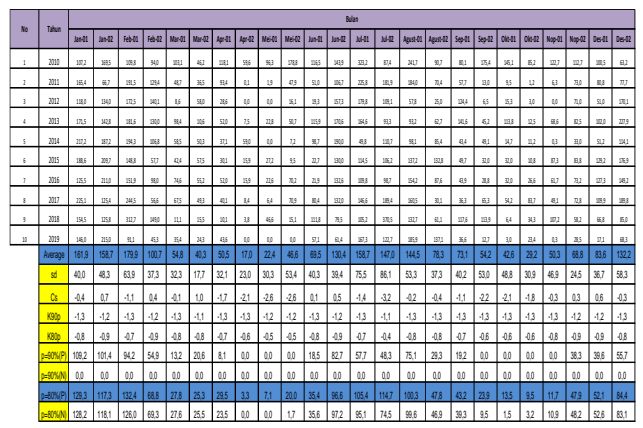

Sumber : Hasil Perhitungan (2019)

ketersediaan air salah satunya adalah metode NRECA (Non Recorded Catchment Area). Adapun tahapan perhitungan simulasi hujan-debit dengan metode NRECA per-dua minggu di bulan Januari 2008 adalah sebagai berikut:

- Contoh metode NRECA di dua minggu pertama bulan Januari 2009.

1. Data curah hujan $(\mathrm{P})$

2. Data Evapotranporasi

3. $1<-$ Rech

4. K-Base

5. A

6. Eto

a. Apabila evapotranspirasi<curah hujan maka Eto = evapotranspirasi

b. Apabila evapotranspirasi<curah hujan maka Eto curah hujan

7. Tampungan kelengasan awal $=\mathrm{Wo}(\mathrm{SMC})=260$

8. Tampungan kelengasan awal $=W i=\frac{W o}{100+(0,2 \times P \text { total })}$

9. $\frac{R b}{\text { Eto }}$

10. Evapotranspirasi aktual

11. Water Balance

12. Moist ratio
$=107,24 \mathrm{~mm}($ Tabel 4.3$)$

$=3,85 \mathrm{~mm}$ (Tabel 2.1)

$=0,29$

$=0,35$

$=365,91 \mathrm{~km}^{2}$

$=3,85 \mathrm{~mm}$

$$
=\frac{260}{100+(0,2 \times 2970,80)}=0,37
$$

$=\frac{R b}{E t o}=\frac{107,24}{3.85}=27,85$

$=\mathrm{AET}=1 \times \frac{A E T}{E t o} \times$ Eto

$$
=1 \times 1 \times 3,85=3,85 \mathrm{~mm}
$$

$=\mathrm{P}-\mathrm{AET}=107,24-3,85=103,39 \mathrm{~mm}$

$=\mathrm{Wi}=0,37$ 
13. Rasio Excess Moisture

$=0,5+\frac{\left(1+\left(\left(2.718^{\wedge}(2 * \mathrm{WI}-1)-2.718^{\wedge}((-2) *(\mathrm{WI}-1))\right)\right.\right.}{\left.\left(\left(2.718^{\wedge}(2 * \mathrm{WI}-1)+2.718^{\wedge}((-2) *(\mathrm{WI}-1))\right)\right)\right)}=0,18$

14. Excess moist

$=18,84 \mathrm{~mm}$

15. Recharge (RECH)

$=$ Excess Moisture $x$ Krech

$=18,84 \times 0,29=5,46 \mathrm{~mm}$

16. Interflow

= Excess Moisture x Recharge

$=18,84-5,46=13,37 \mathrm{~mm}$

17. Ground Water Flow

$=45 \mathrm{~mm}$

18. Baseflow

= Ground Water Flow $x$ Kbase

$=45 \times 0,35=15,75 \mathrm{~mm}$

19. Total Flow

$=$ Base flow + Inter flow

$=15,75+13,37=29,12 \mathrm{~mm}$

20. $Q$ (Bulan)

$=$ Total flow $\times$ A $\times 1000=10656631,43 \mathrm{~m}^{3} / \mathrm{bln}$

21. $Q$ (Detik)

$=\frac{Q(\text { Bulan })}{15 \times 24 \times 3600}$

$=\frac{10656631,43}{16 \times 24 \times 3600}=7,71 \mathrm{~m}^{3} /$ detik

- Contoh metode NRECA di dua minggu terakhir bulan Januari 2010.

1. Data curah hujan (P)

$=169,52 \mathrm{~mm}($ Tabel 4.3$)$

2. Data Evapotranporasi

3. $1<-$ Rech

$=3,85 \mathrm{~mm}($ Tabel 2.1$)$

4. K-Base

$=0,29$

5. A

$=0,35$

6. Eto

$=365,91 \mathrm{~km}^{2}$

$=3,85 \mathrm{~mm}$

a.Apabila evapotranspirasi<curah hujan maka Eto = evapotranspirasi

b.Apabila evapotranspirasi<curah hujan maka Eto curah hujan

7. Tampungan kelengasan awal $=$ Wo $(\mathrm{SMC})=344,56$

8. Tampungan kelengasan awal $=W i=\frac{W o}{100+(0,2 \times P \text { total })}$

$$
=\frac{344,56}{100+(0,2 \times 2970,80)}=0,50
$$

9. $\frac{R b}{E t o}$

$=\frac{R b}{E t o}=\frac{169,52}{3.85}=44,02$

10. Evapotranspirasi aktual

$=\mathrm{AET}=1 \times \frac{A E T}{\text { Eto }} x$ Eto

$$
=1 \times 1 \times 3,85=3,85 \mathrm{~mm}
$$

11. Water Balance

12. Moist ratio

$=\mathrm{P}-\mathrm{AET}=169,52-3,85=225,58 \mathrm{~mm}$

$=\mathrm{Wi}=0,50$

13. Rasio Excess Moisture

$=0,5+\frac{\left(1+\left(\left(2.711^{\wedge}(2 * \mathrm{WI}-1)-2.718^{\wedge}((-2) *(\mathrm{WI}-1))\right)\right.\right.}{\left.\left(\left(2.718^{\wedge}(2 * \mathrm{WI}-1)+2.718^{\wedge}((-2) *(\mathrm{WI}-1))\right)\right)\right)}=0,27$

14. Excess moist

$=44,09 \mathrm{~mm}$

15. Recharge (RECH)

= Excess Moisture $x$ Krech

$=44,09 \times 0,29=12,79 \mathrm{~mm}$

16. Interflow

= Excess Moisture $x$ Recharge $44,09-12,79=31,30 \mathrm{~mm}$

17. Ground Water Flow $=45 \mathrm{~mm}+$ Recharege (pada dua minggu pertama bulan januari) - Baseflow (pada dua minggu pertama bulan januari) $=45+5,46-15,75=34,71 \mathrm{~mm}$ 
18. Baseflow

19. Total Flow

20. $Q$ (Bulan)

21. $Q$ (Detik)
= Ground Water Flow x Kbase

$=34,71 \times 0,35=12,15 \mathrm{~mm}$

= Base flow + Inter flow

$=12,15+31,30=43,45 \mathrm{~mm}$

$=$ Total flow $\times$ A $\times 1000=15899317,94 \mathrm{~m}^{3} / \mathrm{bln}$

$=\frac{Q(\text { Bulan })}{15 \times 24 \times 3600}$

$=\frac{15899317,94}{15 \times 24 \times 3600}=11,50 \mathrm{~m}^{3} / \mathrm{detik}$

Tabel 4.13 Tabel Hasil Perhitungan P80 Tahun 2010 - 2019 Menggunakan Metode NRECA

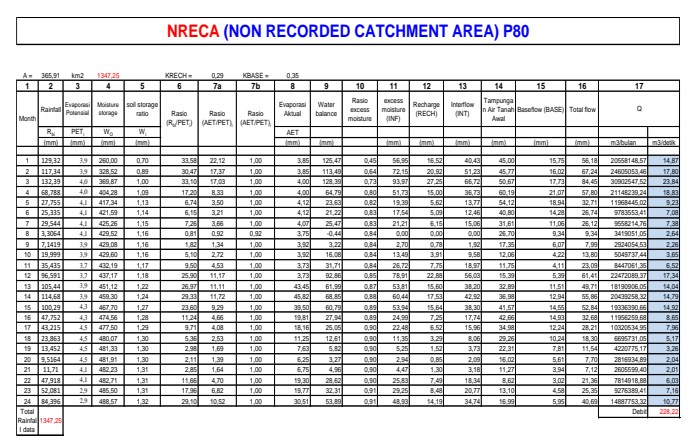

Tabel 4.14 Tabel Hasil Perhitungan Rerata Hujan Tahun 2010 - 2019 Menggunakan Metode NRECA

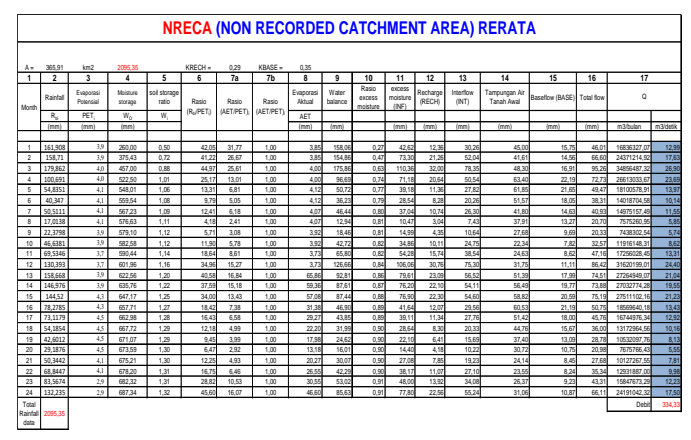


Tabel 4.25 Perhitungan Total Kebutuhan Air Pada DAS Way Sukadana

\begin{tabular}{|c|c|r|r|r|r|r|r|r|r|r|r|r|r|}
\hline \multirow{2}{*}{ NO } & NAMA & \multicolumn{10}{|c|}{ Kebutuhan Air DAS Way Sukadana (m3/dt) } \\
\cline { 2 - 14 } & WATER DISTRICT & Jan-01 & Jan-02 & Feb-01 & Feb-02 & Mar-01 & Mar-02 & Apr-01 & Apr-02 & Mei-1 & Mei-2 & Jun-01 & Jun-02 \\
\hline \multirow{2}{*}{1} & Way Sukadana & 3,03 & 3,12 & 2,35 & 3,48 & 2,22 & 1,59 & 2,10 & 1,77 & 1,43 & 1,27 & 2,46 & 2,54 \\
\hline
\end{tabular}

Sambungan dari tabel diatas

\begin{tabular}{|r|r|r|r|r|r|r|r|r|r|r|r|r|r|}
\hline \multicolumn{10}{|c|}{ Kebutuhan Air DAS Way Sukadana (m3/dt) } & \multirow{2}{*}{ Rata-rata } & $\begin{array}{c}\text { Total } \\
\text { (m3/dtk) }\end{array}$ \\
\hline Jul-01 & Jul-02 & Agu-1 & Agu-2 & Sep-01 & Sep-02 & Okt-1 & Okt-2 & Nop-01 & Nop-02 & Des-1 & Des-2 & & \\
\hline 2,17 & 0,53 & 0,53 & 0,53 & 0,53 & 0,53 & 0,53 & 0,53 & 0,53 & 3,16 & 2,57 & 2,90 & 1,7643 & 42,34 \\
\hline
\end{tabular}

Total kebutuhan air pada DAS Way Sukadana Didapat dari menjumlahkan kebutuhan air penduduk, ternak, industri, dan irigasi. Dengan rumus :

Kebutuhan Air DAS Way Sukadana $=\sum$ Keb.Penduduk $+\sum$ Keb.Ternak + $\sum K e b$. Industri $+\sum$ Keb.Irigasi

Kebutuhan Air DAS Way Sukadana $=11,31 \mathrm{~m}^{3} /$ detik $+0,224 \mathrm{~m}^{3} / \operatorname{detik}+1,131$ $\mathrm{m}^{3} / \operatorname{detik}+29,68 \mathrm{~m}^{3} / \operatorname{detik}=42,34 \mathrm{~m}^{3} / \operatorname{detik}$

Dari hasil perhitungan kebutuhan air diatas, didapat total kebutuhan air pada daerah aliran sungai Way Sukadana seperti sebesar 42,34 m3/detik, dengan persentase masing-masing kebutuhan yaitu:

Persentase Kebutuhan $\quad=\frac{\text { Kebutuha air }}{\text { Total Kebutuhan air }} \times 100 \%$

- Kebutuhan Air Penduduk $=\frac{11,31}{42,34} \times 100 \%=26,7 \%$

- Kebutuhan Air Ternak $=\frac{0,224}{42,34} \times 100 \%=0,5 \%$

- Kebutuhan Air Industri $=\frac{1,131}{42,34} \times 100 \%=2,7 \%$

- Kebutuhan Air Irigasi $=\frac{29,68}{42,34} \times 100 \%=71 \%$

\section{Analisis Neraca Air Daerah Aliran Sungai Way Sukadana}

Analisis neraca air merupkan perhitungan perbandingan antara ketersediaan dan kebutuhan air total pada Daerah Aliran Sungai Way Sukadana. Setelah diperoleh ketersediaan dan kebutuhan air di DAS Way Sukadana, maka dapat dilihat pada grafik 4.2 keseimbangan air pada DAS Way Sukadana berada pada level surplus. Dengan persentase surplus yang dapat dihitung dengan rumus :

Persentase Surplus $=\frac{\text { Total Ketersediaan air }- \text { Total Kebutuha air }}{\text { Total Ketersediaan air }} \times 100 \%$

Persentase Surplus $=\frac{228,22-42,34}{228,22} \times 100 \%$

$$
=81 \%
$$




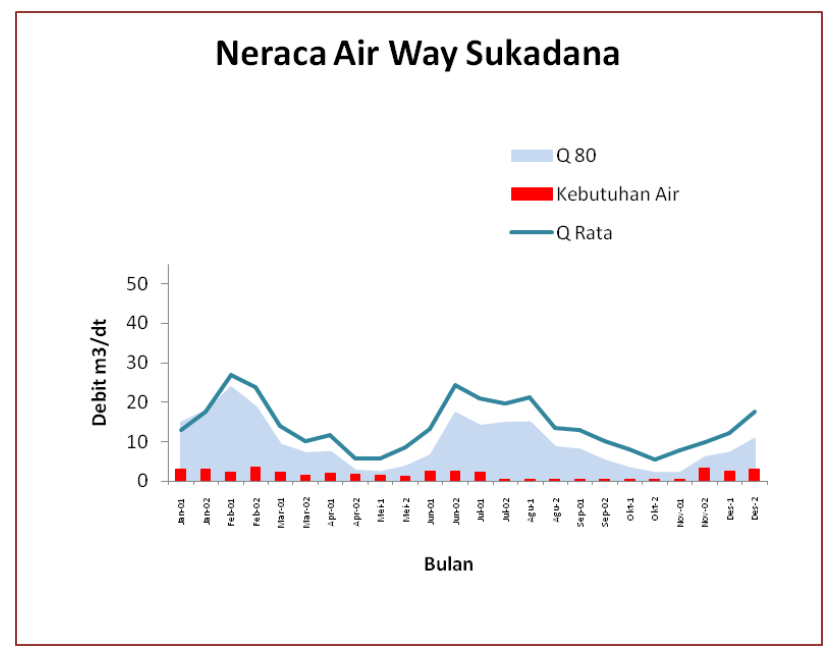

Gambar 4.2 Grafik Neraca Air DAS Way Sukadana 2019

Berdasarkan analisis perhitungan kebutuhan air dan ketersediaan air diatas, grafik neraca air menunjukan ketersediaan air di DAS Way Sukadana cukup atau berada pada level Surplus dengan persentase $81 \%$.

Tabel 4.40 Perhitungan Total kebutuhan air pada DAS Way Sukadana s/d Tahun 2029

\begin{tabular}{|c|c|r|r|r|r|r|r|r|r|r|r|r|r|}
\hline \multirow{2}{*}{ NO } & NAMA & \multicolumn{10}{|c|}{ Kebutuhan Air DAS Way Sukadana (m3/dt) } \\
\cline { 2 - 13 } & WATER DISTRICT & Jan-01 & Jan-02 & Feb-01 & Feb-02 & Mar-01 & Mar-02 & Apr-01 & Apr-02 & Mei-1 & Mei-2 & Jun-01 & Jun-02 \\
\hline 1 & Way Sukadana & 3,10 & 3,19 & 2,42 & 3,55 & 2,29 & 1,66 & 2,17 & 1,84 & 1,50 & 1,34 & 2,53 & 2,61 \\
\hline
\end{tabular}

Sambungan dari tabel diatas

\begin{tabular}{|r|r|r|r|r|r|r|r|r|r|r|r|r|c|}
\hline \multicolumn{10}{|c|}{ Kebutuhan Air DAS Way Sukadana (m3/dt) } & Rata-rata & Total \\
\hline Jul-01 & Jul-02 & Agu-1 & Agu-2 & Sep-01 & Sep-02 & Okt-1 & Okt-2 & Nop-01 & Nop-02 & Des-1 & Des-2 & m3/dtk & m3/dtk \\
\hline 2,24 & 0,60 & 0,60 & 0,60 & 0,60 & 0,60 & 0,60 & 0,60 & 0,60 & 3,23 & 2,64 & 2,97 & 1,83 & 44,04 \\
\hline
\end{tabular}

Total kebutuhan air pada DAS Way Sukadana pada tahun 2029 yang akan datang didapat dari menjumlahkan kebutuhan air penduduk, ternak, industri, dan irigasi. Dengan rumus :

Kebutuhan Air DAS Way Sukadana $=\sum$ Keb. Penduduk $+\sum$ Keb. Ternak + $\sum$ Keb.Industri $+\sum$ Keb. Irigasi

$=12,78 \mathrm{~m}^{3} /$ detik $+0,302 \mathrm{~m}^{3} /$ detik

$+1,28 \mathrm{~m}^{3} /$ detik $+29,68 \mathrm{~m}^{3} /$ detik $=44,04 \mathrm{~m}^{3} / \mathrm{detik}$

Dari hasil perhitungankebutuhan air diatas, proyeksi sampai dengan tahun 2029 didapat total kebutuhan air pada daerah aliran sungai Way Sukadana sebesar $44,04 \mathrm{~m}^{3} /$ detik, dengan persentase masing-masing kebutuhan yaitu: 
Persentase Kebutuhan $\quad=\frac{\text { Kebutuha air }}{\text { Total Kebutuhan air }} \times 100 \%$

- Kebutuhan Air Penduduk $=\frac{12,78}{44,04} \times 100 \%=29,01 \%$

- Kebutuhan Air Ternak = $\frac{29,68}{44,04} \times 100 \%=67,4 \%$

- Kebutuhan Air Industri $=\frac{1,28}{44,04} \times 100 \%=2,90 \%$

- Kebutuhan Air Irigasi $=\frac{0,302}{44,04} \times 100 \%=0,69 \%$

Persentase Surplus $=\frac{\text { Total Ketersediaan air }- \text { Total Kebutuha air }}{\text { Total Ketersediaan air }} \times 100 \%$

Persentase Surplus $=\frac{228,22-44,34}{228,22} \times 100 \%$ $=80,6 \%$

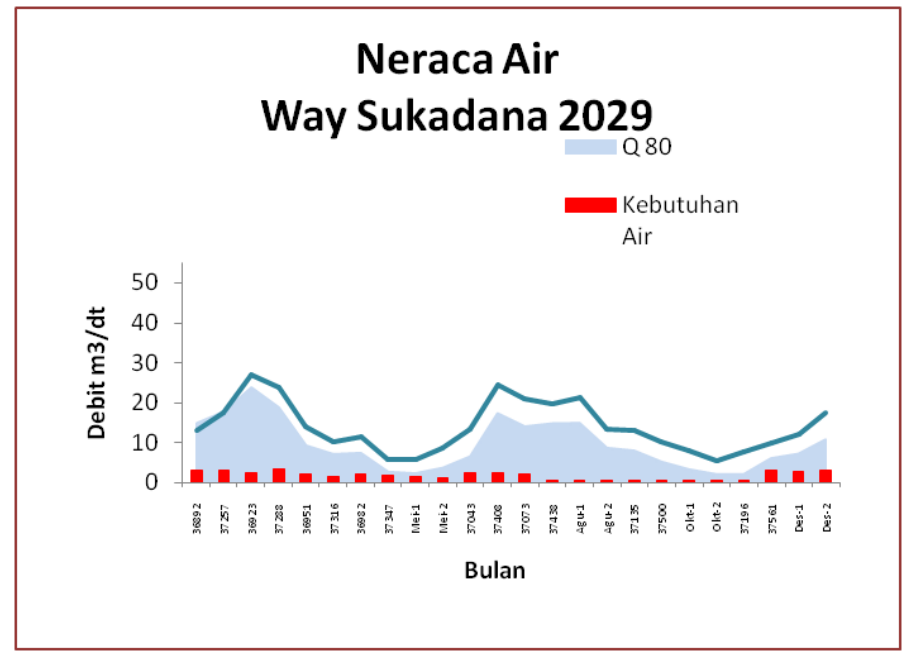

Gambar 4.3 Grafik Neraca Air DAS Way Sukadana 2029

Dari analisis perhitungan kebutuhan air dan ketersediaan air diatas, grafik neraca air menunjukan ketersediaan air di DAS Way Sukadana sampai dengan tahun 2029 cukup atau berada pada level Surplus dengan persentase $80,06 \%$.

\section{Kesimpulan}

Berdasarkan hasil analisis dan pembahasan neraca air DAS Way Sukadana diatas, maka diperoleh kesimpulan sebagai berikut:

1. Kebutuhan air total pada tahun 2019 di DAS Way Sukadana sebesar 42,34 m3/detik.

2 . Kebutuhan air total pada tahun 2029 di DAS Way Sukadana sebesar 44,04 m3/detik.
3.Untuk total Kebutuhan air 10 (sepuluh) tahun yang akan datang pada tahun 2029 sebesar 80,06 m3/detik. Sedangkan ketersediaan air DAS Way Sukadana 228,22 m3/detik dan antara debit Ketersediaan air dengan kebutuhan total air ada surplus sekitar 80,6\%. m3/detik.

\subsection{Saran}

Berdasarkan hasil analisis dan pembahasan diatas, telah didapat kesimpulan bahwa Daerah Aliran Sungai Way Sukadana beraada pada level surplus. Oleh sebab itu, saran yang dapat diberikan adalah:

1. Kelebihan air pada DAS Way Sukadana dapat dimanfaatkan 
dengan dilakukannya pembangunan infrastruktur berupa tampungan air seperti embung, bendungan atau kolam air. Sehingga kelebihan air tersebut dapat dimanfaatkan dengan baik.

2. Dalam rangka pemanfaatan sumber daya air di DAS Way Sukadana, penelitian ini dapat dimanfaatkan dan dikembangkan.

\section{DAFTAR PUSTAKA}

Anonim, 2000, Informasi Obat Nasional Indonesia, Direk Jendral Pengawasan Obat dan Makanan, hal 47, Depkes RI, Indonesia.

Asdak, Chay. (2010). Hidrologi dan Pengelolaan Daerah Aliran Air Sungai: Edisi Revisi Kelima. Yogyakarta: Gadjah Mada University Press Yogyakarta

Asdak,Chay, 2002, Hidrologi Dan Pengelolaan Daerah Aliran Sungai, Gajah Mada University Press, Yogyakarta.

BBWS Mesuji Sekampung (2010). Dokumen Pola Pengelolaan Sumber Daya Air Wilayah Sungai SeputihSekampung. Lampung.

BBWS Mesuji Sekampung (2017). Dokumen Pola Pengelolaan Sumber Daya Air Wilayah Sungai SeputihSekampung. Lampung.

BPS Kabupaten Lampung Timur (2019). Kecamatan Sukadana Dalam Angka. Lampung Timur.

BPS Kabupaten Lampung Timur (2019). Kecamatan Way Bungur Dalam Angka. Lampung Timur.

BPS Kabupaten Lampung Timur (2019). Kecamatan Purbolinggo Dalam Angka. Lampung Timur.

BPS Kabupaten Lampung Timur (2019). Kecamatan Bumi Agung Dalam Angka. Lampung Timur.
Departemen Pekejaan Umum, 2010. Standar Perencanaan Irigasi Kriteria Perencanaan Bagian Jaringan Irigasi KP-01, CV Galang Persada, Bandung.

Departemen Pekejaan Umum, 2010. Standar Perencanaan Irigasi Kriteria Perencanaan Bagian Saluran KP-03, CV Galang Persada, Bandung.

Departemen Pekejaan Umum, 2010. Standar Perencanaan Irigasi Kriteria Perencanaan Bagian Saluran KP-04, CV Galang Persada, Bandung.

Direktorat Jendral Cipta Karya (2000). Buku Panduan Pengembangan Air Minum. Bina Program. Jakarta

Ditjen Cipta Karya, 2000. Kriteria Perencanaan Air Bersih. Ditjen Cipta Karya, Departemen Pekerjaan Umum.

Doorenbos, J. and W.O. Pruitt. 1977. Guidelines for Predicting Crop Water

https://cjournal.unsrat.ac.id/index.php/i ss/article/viewFile/17638/17158 http://abmaddamopolii.info/2016/03/21 /pemanfaatan-air-domestik-part-l/

Kindler, J. And C.S. Russel. 1984. Modeling Water Demands. Academic Press Inc. London.

Loebis, Joesron, 1987. Banjir Rencana untuk Bangunan Air, Badan Penerbit Pekerjaan Umum, Bandung.Maret. Surakarta.Obat dan Makanan, hal 47, Depkes RI, Indonesia.

Petunjuk praktis Perencanaan Pembangunan Sistem Penyediaan Air Bersih Pedesaan. Departemen Pekerjaan Umum, Direktorat Jenderal Cipta Karya.Requirement. Food and Agriculture Organization of The United Nation.Rome.

Silalahi, M.D. 2002. Optimalisasi Sarana Yuridis Sebagai Upaya Menumbuhkan Masyarakat Sadar Urgensi Sumber 
Daya Air (SDA). Majalah Air Minum, edisi No.97/th.XXIII Desember 2002.

Sosrodarsono, Suyono, \& Takeda, Kensaku, 1977. Bendungan Tipe Urugan, Pradnya Paramita, Jakarta.

Triatmodjo Bambang, 2008. Hidrologi Terapan. Beta Offset, Yogyakarta.

Devi Peggy Utami. (2019) Analisis Neraca Air Daerah Aliran Sungai (DAS) Way Pisang. Universitas Bandar Lampung. 